Spider Silk 
This page intentionally left blank 


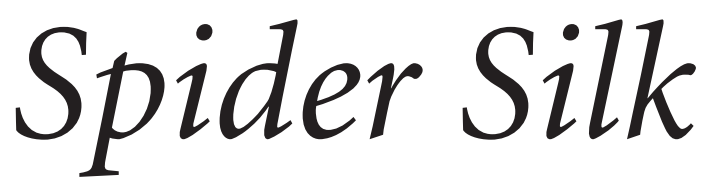

\title{
Evolution and 400 Million Years of Spinning, Waiting, Snagging, and Mating
}

\author{
LESLIE BRUNETTA \\ CATHERINE L. CRAIG
}


Copyright (c) 2010 by Leslie Brunetta and Catherine L. Craig. All rights reserved.

This book may not be reproduced, in whole or in part, including illustrations, in any form (beyond that copying permitted by Sections 107 and 108 of the U.S. Copyright Law and except by reviewers for the public press), without written permission from the publishers.

Yale University Press books may be purchased in quantity for educational, business, or promotional use. For information, please e-mail sales.press@yale.edu (U.S. office) or sales@yaleup.co.uk (U.K. office).

Set in Minion type by The Composing Room of Michigan, Inc. Printed in the United States of America.

Library of Congress Cataloging-in-Publication Data Brunetta, Leslie, 1960-

Spider silk : evolution and 400 million years of spinning, waiting, snagging, and mating / Leslie Brunetta and Catherine L. Craig. p. cm.

Includes bibliographical references and index.

ISBN 978-0-300-14922-7 (alk. paper)

1. Spider webs. 2. Spiders-Anatomy. 3. Spiders, Fossil.

4. Evolution (Biology) I. Craig, Catherine Lee. II. Title.

QL459.B78 2010

$595.4^{\prime} 4$ - dc22 2009047224

A catalogue record for this book is available from the British Library.

This paper meets the requirements of ANSI/NISO

Z39.48-1992 (Permanence of Paper).

$\begin{array}{llllllllll}10 & 9 & 8 & 7 & 6 & 5 & 4 & 3 & 2 & 1\end{array}$ 
For Pete, whose patience has extended nearly 400 million years For Bob, whose love, laughter, and support make it work 
Once you begin watching spiders, you haven't time for much elsethe world is really loaded with them.

—E. B. White, "Pigs and Spiders" 